\title{
Wear Behaviour of Al6063-Zircon Sand Metal Matrix Composite
}

\author{
K.S.Sucitharan ${ }^{1}$, P.SenthilKumar ${ }^{2}$, D.Shivalingappa ${ }^{3}$, J.Jenix Rino ${ }^{4}$ \\ ${ }^{1,4}$ PG scholar, Department of Mechanical Engineering, \\ Adhiyamaan College of Engineering (Autonomous), Hosur, India \\ ${ }^{2}$ Assistant Professor, ${ }^{3}$ Professor Department of Mechanical Engineering, \\ Adhiyamaan College of Engineering (Autonomous), Hosur, India
}

\begin{abstract}
The Present work is focused on the study of wear behaviour of Aluminium alloy (6063)-Zircon sand composite produced by the stir casting technique by controlling various casting parameters. The pin on disk apparatus is used to analyze the wear rate of the composite. Here the combination of composites investigated is $0,2,4,6,8 \mathrm{wt} \%$ of $\mathrm{ZrSiO}_{4}$ with the matrix and it is found that the increase in reinforcement increase the wear resistant property.
\end{abstract}

Key words: Aluminium Alloy, Zircon Sand, Stir casting, Wear test.

\section{INTRODUCTION}

Metal Matrix Composites have evoked a keen interest in recent times for potential in marines, aerospace and automotive industries owing to their superior strength to weight ratio and high temperature resistance. The aim involved in designing metal matrix composite materials is to combine the desirable attributes of metals and ceramics. The addition of high strength, high modulus refractory particles to a ductile metal matrix produce a material whose mechanical properties are intermediate between the matrix alloy and the ceramic reinforcement ${ }^{[2]}$ Aluminium is the most abundant metal in the Earth's crust, and the third most abundant element, after oxygen and silicon. It makes up about $8 \%$ by weight of the Earth's solid surface. Due to easy availability, high strength to weight ratio, easy machinability, durable, ductile and malleability. Aluminium is the most widely used non-ferrous metal in 2005 was 31.9 million tones ${ }^{[3]}$

\subsection{Aluminium as matrix}

Aluminium matrix composites (AMCs) have been widely studied since the 1920s and are now used in sporting goods, electronic packaging, armors and automotive industries. Aluminium is the most popular matrix for the metal matrix composites (MMCs). The Al alloys are quite attractive due to their low density, their capability to be strengthened by precipitation, their good corrosion resistance, high thermal and electrical conductivity, and their high damping capacity [1].

\subsection{Zircon sand as Reinforcement}

Zircon Sand consists of mostly Zirconium Silicate $\left(\mathrm{ZrSiO}_{4}\right)$ and some hafnium in addition to some rare earth elements, titanium minerals, monazite, etc. Zircon Sand is used chiefly for facing on foundry moulds to increase the resistance against metal penetration. Milled zircon sand is used in refractory paint for coating the outside of moulds.

Zircon Sand deposits have been found in abundance near Indian coastal regions of Kerala, Tamil Nadu and Orissa. Zircon Sand was found to be a promising candidate as reinforcement material for aluminium, zinc and lead based composites. The last property is important since fabrication processes require drastic changes in temperature and large volumetric changes due to phase transformations can caused bonding at the interface. Furthermore, Zircon Sand possesses a very low thermal expansion coefficient compared to most other ceramic oxides. ${ }^{[6]}$

Therefore, a change in temperature would not give rise to very high thermal stresses within Zircon Sand particles. Zircon Sand particles can be incorporated to aluminium silicon alloy matrix by stir casting route and the dispersed amount can be further increased by the addition of magnesium in the melt. 
Table 1.1 Properties of zircon sand

\begin{tabular}{|l|c|}
\hline \multicolumn{1}{|c|}{ Properties } & Zircon Sand \\
\hline M.P. (_C) & 2500 \\
\hline Limit of application (C) & 1870 \\
\hline Hardness (Moh_s Scale) & 7.5 \\
\hline Density (g/ $\left.\mathrm{cm}^{3}\right)$ & $4.5-4.70$ \\
\hline Linear seeff. of expansion (10- $\left.{ }^{6} \mathrm{~K}\right)$ & 4.5 \\
\hline Fracture toughness (MPa-m $\left.{ }^{1 / 2}\right)$ & 5 \\
\hline Crystal structure & Tetragonal \\
\hline
\end{tabular}

\subsection{Al606}

\section{RAW MATERIALS}

The materials utilized in the present study are 100 percent pure Zircon sand $(\mathrm{ZrSiO} 4)$ particles and Aluminium 6063 alloy which served as the matrix.

The composition of the Aluminium 6063 alloy is shown in Table 2.1

Table 2.1 Chemical Composition of Aluminium 6063 Alloy

\begin{tabular}{|c|c|c|c|c|c|c|c|}
\hline $\mathrm{Si}$ & $\mathrm{Fe}$ & $\mathrm{Cu}$ & $\mathrm{Mn}$ & $\mathrm{Mg}$ & $\mathrm{Cr}$ & $\mathrm{Ni}$ & $\mathrm{Zn}$ \\
\hline 0.431 & $0.102 \%$ & $0.0073 \%$ & $0.029 \%$ & $0.50 \%$ & $0.0026 \%$ & $0.0036 \%$ & $0.0049 \%$ \\
\hline $\mathrm{Ti}$ & $\mathrm{Ag}$ & $\mathrm{B}$ & $\mathrm{Be}$ & $\mathrm{Bi}$ & $\mathrm{Ca}$ & $\mathrm{Co}$ & $\mathrm{Li}$ \\
\hline 0.013 & $<0.0001 \%$ & $<0.026 \%$ & $<0.0001 \%$ & $<0.001 \%$ & $0.0037 \%$ & $<0.001 \%$ & $<0.0002 \%$ \\
\hline $\mathrm{Na}$ & $\mathrm{Pb}$ & $\mathrm{SA}$ & $\mathrm{Sr}$ & $\mathrm{V}$ & $\mathrm{Zr}$ & $\mathrm{Cd}$ & $\mathrm{Al}$ \\
\hline 0.0024 & $0.0086 \%$ & $0.0026 \%$ & $<0.0001 \%$ & $0.0079 \%$ & $0.0010 \%$ & $<0.0001 \%$ & $98.8 \%$ \\
\hline
\end{tabular}

\subsection{Zircon Sand:}

The Zircon sand particle size range between 2-4 microns used as reinforcement. The reinforcements were sieved and selected which is $99.99 \%$ pure.

\section{EXPERIMENTAL SETUP}

\subsection{Stir Casting Process:}

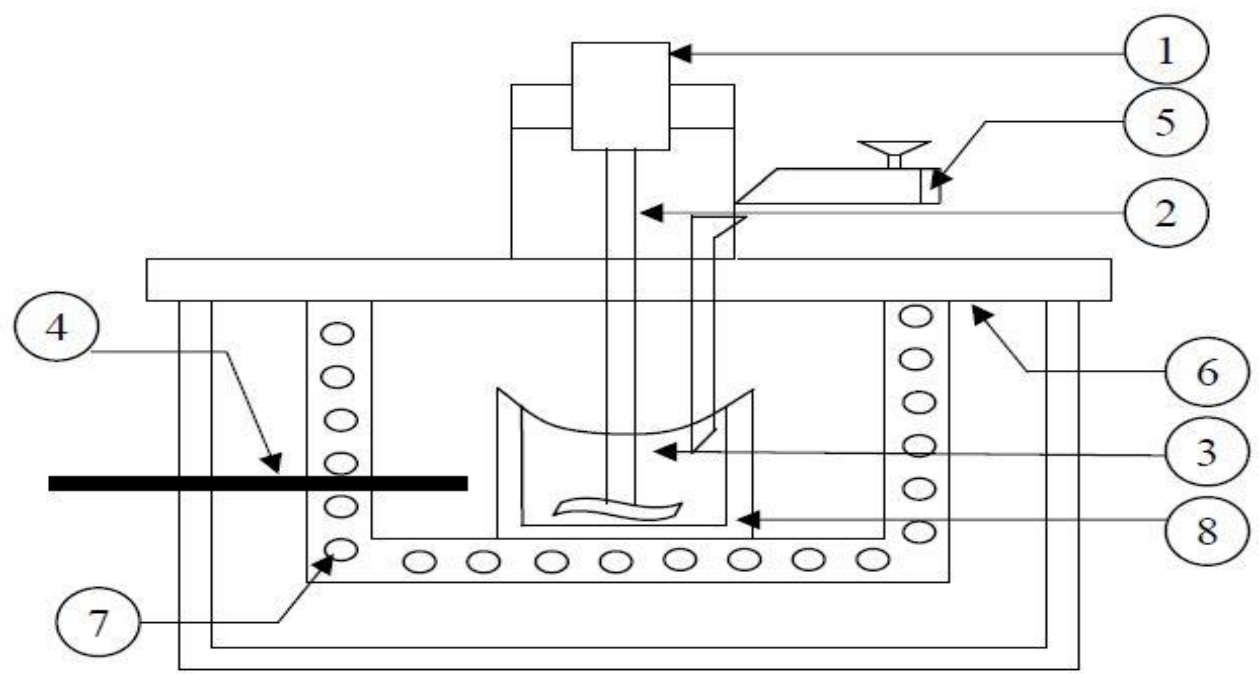

Fig: 3.1 Schematic view of setup for Fabrication of AMC via stir casting technique ${ }^{[5]}$ 
1. Motor. 2. Shaft. 3. Molten aluminium. 4. Thermocouple. 5. Particle injection chamber. 6. Insulation hard board. 7. Furnace. 8. Graphite crucible.

Aluminium (6063) alloy and $\mathrm{ZrSiO}_{4}$ particles required to produce the composites having 2,4, 6, and 8 weight percent zircon sand were synthesized successfully by stir casting technique. The zircon sand particles were preheated to $600^{\circ} \mathrm{C}$ for improving the wetability with the $\mathrm{Al}(6063)$ alloy. The $\mathrm{Al}(6063)$ alloy ingots were charged into a gas-fired crucible furnace and heated to a temperature of $750^{\circ} \mathrm{C} \pm 30^{\circ} \mathrm{C}$ (above the liquid us temperature of the alloy) and the liquid alloy was then allowed to cool in the furnace to a semi solid state at a temperature of about $600^{\circ} \mathrm{C}$. The preheated zircon sand was added at this temperature and stirring of the slurry was performed manually for 5minutes. The composite slurry was then superheated to $720^{\circ} \mathrm{C}$ and a second stirring performed using a mechanical stirrer. The stirring operation was performed at a speed of 300rpm for 10minutes to help improve the distribution of the zircon sand particles in the molten $\mathrm{Al}$ (6063) alloy. The molten composite was then cast into prepared sand moulds. $\mathrm{Al}$ (6063) alloy without reinforcement was also prepared for control experimentation.

Table 3.1 percentage Composition of composites

\begin{tabular}{|c|c|c|}
\hline Samples & A1 6063 & $\mathrm{ZrSiO}_{4}$ \\
\hline 1 & $100 \%$ & $0 \%$ \\
\hline 2 & $98 \%$ & $2 \%$ \\
\hline 3 & $96 \%$ & $4 \%$ \\
\hline 4 & $94 \%$ & $6 \%$ \\
\hline 5 & $92 \%$ & $8 \%$ \\
\hline
\end{tabular}

\subsection{Wear test}

Wear occurs as a natural consequence when two surfaces with a relative motion interact with each other. Wear may be defined as the progressive loss of material from contacting surfaces in relative motion. We know that one third of our global energy consumption is consumed wastefully in friction. Wear causes an enormous annual expenditure by industry and consumers. Most of this is replacing or repairing equipment that has worn to the extent that it no longer performs a useful function ${ }^{[4]}$.

The amount of wear generated depends upon the applied load, sliding speed, sliding distance, material properties and environment. For getting reliable and repeatable wear data, contact between the wear disc and the specimen pin is to be $100 \%$ and virgin material of specimen pin is to be exposed to the wear disc ${ }^{[7]}$. EN-31 steel disc has been used with hardness of $60 \mathrm{HRC}$ and the pin was prepared in the dimension of $8 \mathrm{~mm}$ dia and 50 mm length as per ASTM G99-95 standards. the pins ware tested against content load of $9.81 \mathrm{~N}$ and varying velocities as follows $2.5 \mathrm{~m} / \mathrm{s}, 3 \mathrm{~m} / \mathrm{s}, 3.5 \mathrm{~m} / \mathrm{s}, 4 \mathrm{~m} / \mathrm{s}$.

\section{RESULT AND DISCUSSION}

From the wear test conducted via pin on disc method we got the following comparative graphs in terms of wear rate verses time

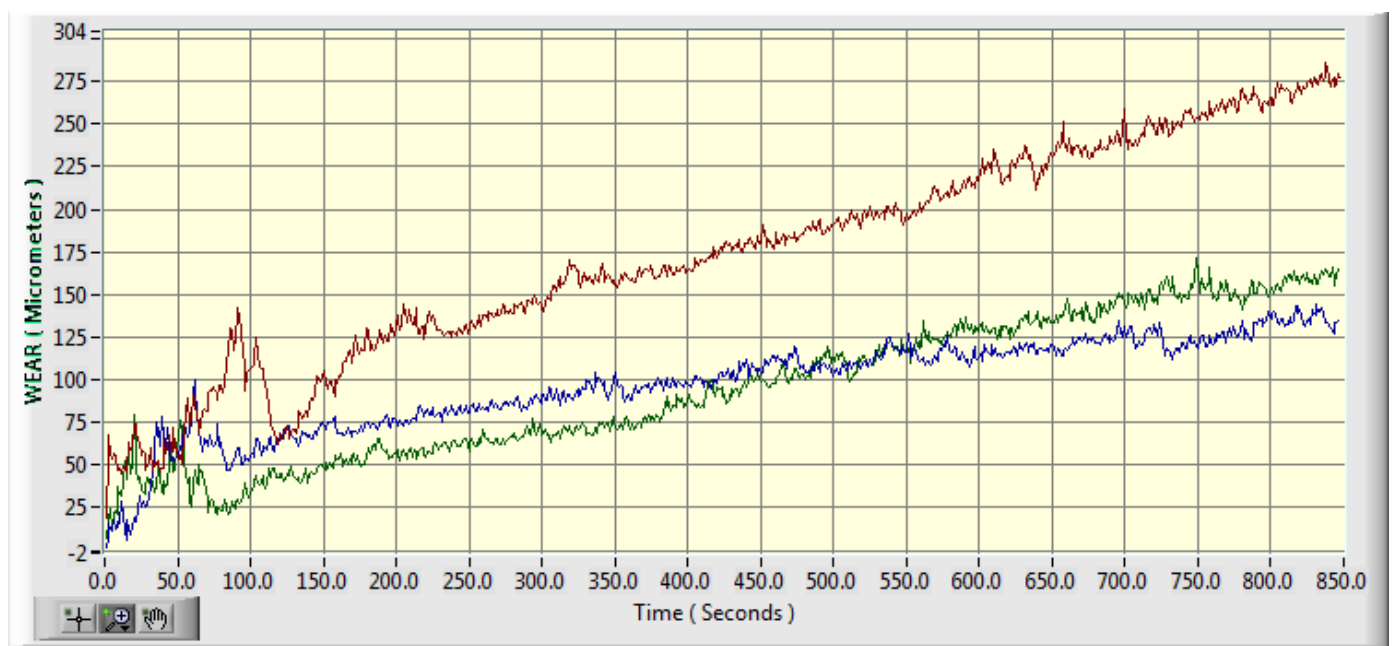

Fig:4.1 $\mathrm{Al} 6063+0 \% \mathrm{Zr}_{2} \mathrm{SiO}_{4}, \mathrm{Al} 6063+4 \% \mathrm{Zr}_{2} \mathrm{SiO}_{4}, \mathrm{Al} 6063+8 \% \mathrm{Zr}_{2} \mathrm{SiO}_{4}$ at $2.5 \mathrm{~m} / \mathrm{s}$ sliding velocity 


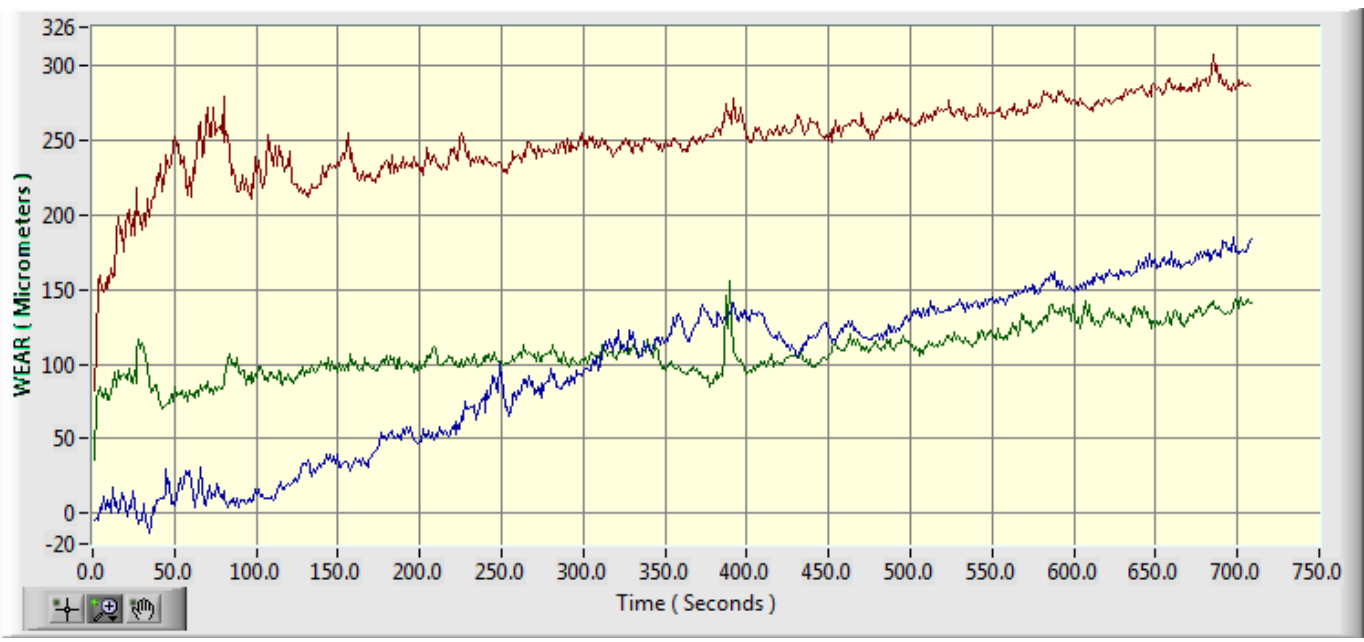

Fig:4.2 $\mathrm{Al} 6063+0 \% \mathrm{Zr}_{2} \mathrm{SiO}_{4}, \mathrm{Al} 6063+4 \% \mathrm{Zr}_{2} \mathrm{SiO}_{4}, \mathrm{Al} 6063+8 \% \mathrm{Zr}_{2} \mathrm{SiO}_{4}$ at $3 \mathrm{~m} / \mathrm{s}$ sliding velocity

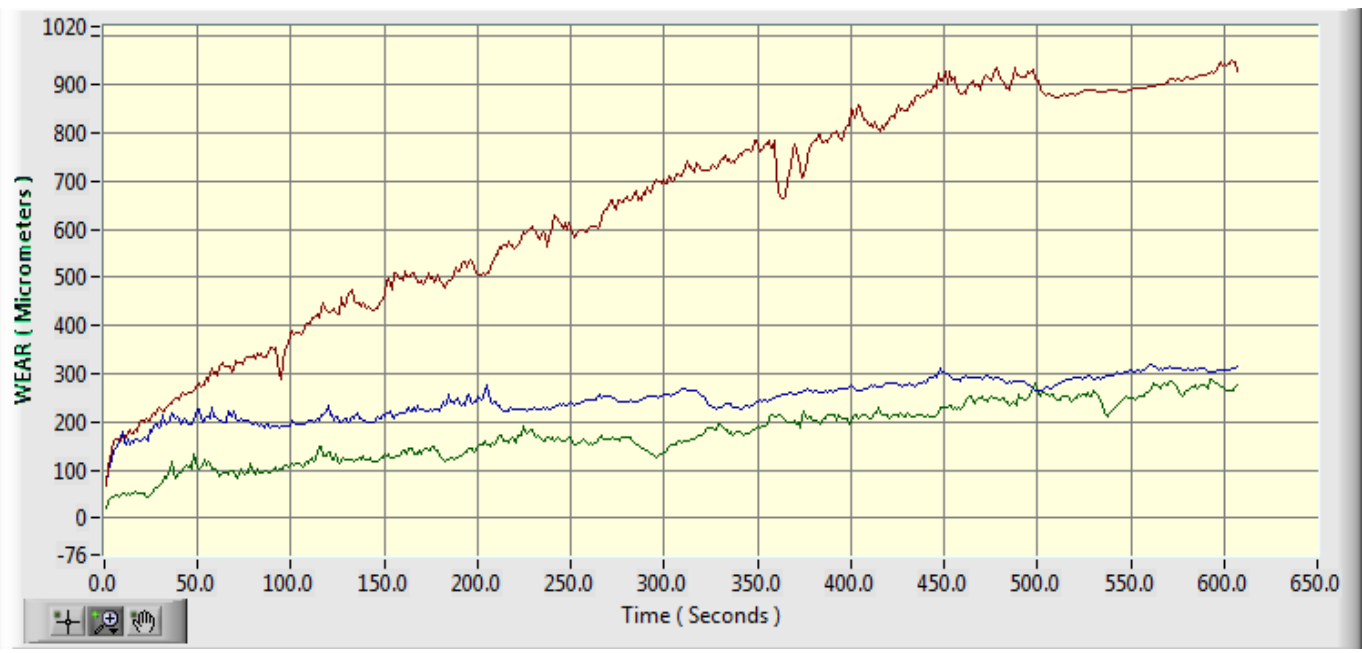

Fig:4.3 $\mathrm{Al} 6063+0 \% \mathrm{Zr}_{2} \mathrm{SiO}_{4}, \mathrm{Al} 6063+4 \% \mathrm{Zr}_{2} \mathrm{SiO}_{4}, \mathrm{Al} 6063+8 \% \mathrm{Zr}_{2} \mathrm{SiO}_{4}$ at $3.5 \mathrm{~m} / \mathrm{s}$ sliding velocity

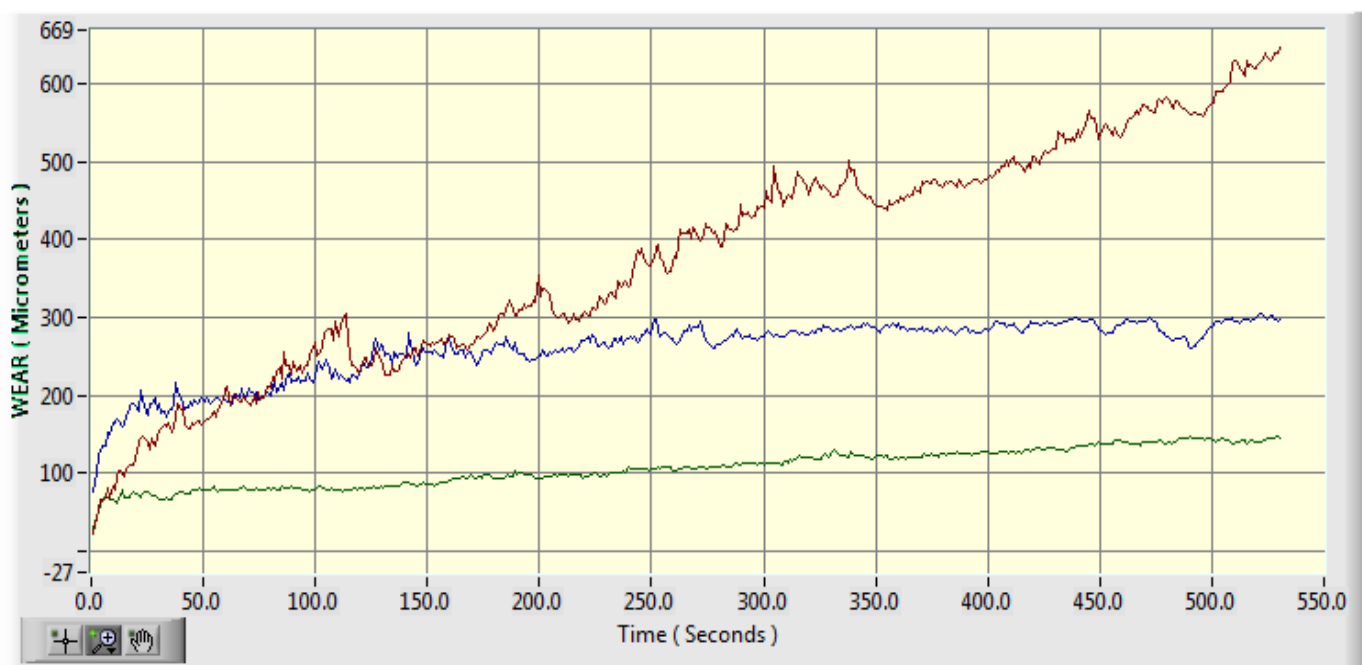

Fig:4.4 $\mathrm{Al} 6063+0 \% \mathrm{Zr}_{2} \mathrm{SiO}_{4}, \mathrm{Al} 6063+4 \% \mathrm{Zr}_{2} \mathrm{SiO}_{4}, \mathrm{Al} 6063+8 \% \mathrm{Zr}_{2} \mathrm{SiO}_{4}$ at $4 \mathrm{~m} / \mathrm{s}$ sliding velocity

The resultant graphs clearly shows the increase of wear resistant according to the increase of the reinforcement percentage. Particularly on testing the specimen of $8 \% \mathrm{ZrSiO}_{4}$ at $2.5 \mathrm{~m} / \mathrm{s}$ and $3 \mathrm{~m} / \mathrm{s}$ the wear at starting is slightly higher than the wear accrued in $4 \% \mathrm{ZrSiO} 4$ reinforced specimen but later the wear curve gets decline then that which is due to the temperature resistance of the zirconium silicate particles. 


\section{CONCLUSION}

The following conclusions can be drawn from the present work:

AL 6063 alloy matrix composites reinforced with Zircon Sand particles can be successfully synthesized by the stir casting method. For successfully synthesisation of composite by stir casting process, stirrer design and position, stirring speed and time, melting and pouring temperature, particle-preheating temperature, particle incorporation rate, mould type and size, and reinforcement particle size and amount are the important process parameters.

Wear behaviour of Al6063 /Zircon Sand MMCs is tested by Pin on disk method and found Increasing in the percentage of Zircon Sand particles will reduce the wear rate where the composite having $8 \mathrm{wt} \% \mathrm{ZrSiO}_{4}$ having the higher wear resistance rate.

\section{REFERENCES}

[1] Daniel B. Miracle and Steven L. Donaldson, "Introduction to Composites", ASM Hand Book of Composite Materials, volume- 21 .

[2] Hashim J et al., "Metal matrix composites: production by the stir casting method", Journal of Materials Processing Technology 92-93 (1999) 1-7.

[3] http://en.wikipedia.org/wiki/Aluminium.htm on date 1/4/2011

[4] J.Jenix Rino, D.Chandramohan, K.S.Sucitharan,"An Overview On Development Of Aluminium Metal Matrix Composites With Hybrid Reinforcement",IJSR India Online ISSN 2319-7064.

[5] J.Jenix Rino, D.Chandramohan, V.Daniel Jebin "Research Review On Corrosion Behaviour Of Metal Matrix Composites", ISSN: 0975-833X.

[6] Nigamanada ray, Dilip kumar kerketta, "Some Studies on Aluminium Matrix in Situ Composites Produced by Stir Casting Method", ME Thesis NIT Rourkela, 2010.

[7] Wear and friction monitor instruction manual for installation, operation and maintenance, DUCOM, Bangalore, India July 2002. 